\title{
The perseverance of the saints, persecution and mission, and its implications for Reformed churches
}

Author:

Pieter Verster ${ }^{1}$ (D)

\section{Affiliation:}

${ }^{1}$ Department of Practical and Missional Theology, Faculty of Theology and Religion, University of the Free State, Bloemfontein, South Africa

\section{Corresponding author:}

Pieter Verster,

versterp@ufs.ac.za

Dates:

Received: 28 Jan. 2019

Accepted: 04 June 2019

Published: 22 Aug. 2019

How to cite this article:

Verster, P., 2019, 'The

perseverance of the saints,

persecution and mission, and its implications for Reformed churches', In die Skriflig 53(3),

a2446. https://doi.org/10.4102/

ids.v53i3.2446

\section{Copyright:}

(C) 2019. The Authors. Licensee: AOSIS. This work

is licensed under the

Creative Commons

Attribution License.
Read online:
The confession of saints' perseverance in the Canons of Dort gives much comfort to the Christian. This was one of the most important challenges the Synod of Dort had to address. It also has many implications for the mission of the church. Not only does it highlight the message that God, in his salvation, will always complete his act of redemption, but also that he will not reject the believer once he or she has become a true Christian. It also comforts many in times of persecution, because God, in his faithfulness, will be the One to empower the believer to remain steadfast and also to vow for those who doubt and even struggle to keep the faith. For Reformed churches, this means that, in the endeavour of mission, a message of great comfort can be proclaimed to all. In Jesus Christ there is certainty of eternal life not because of human power or godliness, but because of God's faithfulness. Theologically it is, however, also important to challenge philosophical views where certainty of faith is rejected for a worldview of uncertainty. The truth of faith is, however, found in God, not in the human possibilities. In this regard, Dort is important for the church to be guided to the fullness of service to the triune God. Mission becomes a wonderful act of peace for the troubled soul in a troubled world.

Keywords: Perseverance; Saints; Persecution; Eternity; Reformed churches.

\section{Introduction}

The confession of the perseverance of the saints in the Canons of Dort gives much comfort to the Christian. Essentially, it is a confession that God will keep the believer safe under all circumstances and for eternity. God will comfort the believer. God, in his faithfulness, will be the One that keeps the believer safe. The believer does not have to do something to be saved and to receive eternal life by keeping the faith. God, in his faithfulness, will empower the believer to persevere in faith. This was one of the most important challenges the Fifth National Synod at Dordtrecht from 13 November 1681 had to address. There were many questions regarding eternal election and the assurance of faith as well as whether one can ever be sure of one's eternal salvation. It would be possible to lose one's faith and eternal salvation if God chose by way of the excepted faith and not radically by grace alone. It would then be possible to lose one's faith and not be able to persevere until the end. The churches in the Netherlands were in turmoil regarding these issues (Berkhof \& De Jong 1975:205-206).

\section{The perseverance of the saints in the Canons of Dort}

The message of salvation and the complete act of redemption comes from God. Whenever believers become true Christians, God will keep them in his hand. He will always and under all circumstances be there for the person. What is important is that the Canons of Dort do not imply that the believer does not have any responsibility. The believer has much responsibility to be near to God, to follow God, to yield him- or herself more and more to God, to be in the presence of God, to seek the countenance of God, to live Coram Deo in the nearness of God, under the eyes of God. Three aspects are of importance: First, God is the Saviour and he gives the believer full assurance of faith. Second, this comes only from God's grace. The challenge from the Armenians is exactly that God does not reject the free will of humans and that God saves by seeing that the believer would believe and that there cannot be full assurance of eternal life. Perseverance of faith is thus the task and calling of the believer. However, Dort accepts that the believer has great responsibility, but that the perseverance of faith comes from God. Thirdly, God himself will empower the believer to persevere until the end. The confession of the perseverance of the saints emphasises that whatever may come upon them, God will not reject the true believer. The question is, however, if it is by God's grace and election that believers are saved; what about their own responsibility; and what about the many verses calling for the believers to persevere in faith? Is it not then totally superfluous? 
Dort (Reformed Church in America 1991) explains it clearly:

Article 3: God's preservation of the converted:

Because of these remnants of sin dwelling in them and also because of the temptations of the world and Satan, those who have been converted could not remain standing in this grace if left to their own resources. But God is faithful, mercifully strengthening them in the grace once conferred on them and powerfully preserving them in it to the end.

Article 9: The assurance of this preservation:

Concerning this preservation of those chosen to salvation and concerning the perseverance of true believers in faith, believers themselves can and do become assured in accordance with the measure of their faith. By this faith they firmly believe that they are and always will remain true and living members of the church, and that they have the forgiveness of sins and eternal life.

Article 10: The ground of this assurance:

Accordingly, this assurance does not derive from some private revelation beyond or outside the Word, but from faith in the promises of God which are very plentifully revealed in the Word for our comfort, from the testimony of 'the Holy Spirit testifying with our spirit that we are God's children and heirs' (Rom. 8:1617), and finally from a serious and holy pursuit of a clear conscience and of good works. If God's chosen ones in this world did not have this well-founded comfort that the victory will be theirs and this reliable guarantee of eternal glory, they would be of all people most miserable.

Article 14: God's use of means in perseverance:

And, just as it has pleased God to begin this work of grace in us by the proclamation of the gospel, so God preserves, continues, and completes this work by the hearing and reading of the gospel, by meditation on it, by its exhortations, threats, and promises, and also by the use of the sacraments.

Article 6: Rejection of false accusations:

That the teaching of the Reformed churches on predestination and on the points associated with it by its very nature and tendency draws the minds of people away from all godliness and religion, is an opiate of the flesh and the devil, and is a stronghold where Satan lies in wait for all people, wounds most of them, and fatally pierces many of them with the arrows of both despair and self-assurance.

What is true belief and who is the true Christian? It is important to notice that the Bible does not make a distinction in this regard by saying that some people are true believers and some are not. The only reference to this kind of distinction is the parable of the seeds in the land where the good wheat and the weed grow together and the farmer left it until it was time to reap and only then, he distinguishes between wheat and weed. God knows those who are truly in Christ and will keep them safe.

The perseverance of the Saints is clearly explained in the Bible and in the Canons of Dort.
Sinnema (2011) writes:

On the topic of perseverance of the saints, the emphasis of the Canons is actually on God's preservation of those whom he has regenerated until the end of life; perseverance in faith flows out of that preservation. The converted cannot remain standing in grace by their own resources; rather, God is faithful, strengthening them in the grace conferred on them and powerfully preserving them in it to the end (5.3). For God preserves in those saints his imperishable seed from which they have been born again (5.7). By God's undeserved mercy they neither forfeit faith and grace totally, nor become lost. A similar emphasis can be found in Calvin though he did not offer a sustained treatment of perseverance, this theme is clear here and there throughout his writings. Calvin's emphasis is that perseverance is a gift of Cod, not the merit of the person persevering. It applies only to the elect, whom the Father entrusted to Christ to keep unto eternal life generated by God's Spirit. (pp. 99-100)

\section{MacArthur (1993) also concurs:}

All true believers will be saved to the uttermost. Christ's High Priestly ministry guarantees it. They have been justified, they are being sanctified, and they will be glorified. Not one of them will miss out on any stage of the process, though in this life they all find themselves at different points along the way. (p. 8)

This means that God will save and preserve the saints by way of his generous grace in Christ.

\section{In this regard, Migliore (2004) writes:}

According to the biblical witness, the electing grace of God is astonishing, but not dreadful. In the Bible election means that the God who freely chose Israel as covenant partner and who freely established a new covenant in Jesus Christ with Jew and Gentile alike is the God of free grace. (p. 88)

According to Louis Berkhof (1978:220), Luther and Calvin both regarded the work of God to regenerate the sinner as instantaneous and at once complete. Therefore, the believer can be absolutely sure of his or her salvation in Christ. The future of total acceptance by God is assured.

Calvin (Inst. 3:XXI) lays much emphasis on God's free election as the basis for the perseverance of the believers. Calvin also believed that only the faithful in Christ can be saved. The union with Christ results in regeneration and justification (McGrath 1994:388).

Van der Westhuizen (2018:1-9) argues that the Canons of Dort lack a clear Trinitarian approach. Ambiguity regarding the Tri-unity is, according to him, the reason why a clear Trinitarian theology is absent. However, to my mind, evidence of the deep Christological approach explains the theological position well and should be accepted. In addition, Van der Walt (2011:270, 275; 2012:180) warns against an Aristotelian approach of causality which is, according to him, present in the Canons of Dort. It is regarding God still as immoveable and not in personal relations. Van der Walt is of the opinion that dualism still existed in the explanation of election in the Canons. It not only lacks an integral biblical theological interpretation, but also used philosophical views 
from a Greek background. However, again the Christological view of the Canons makes such criticism questionable. The Canons are deeply Christological and explain election and perseverance absolutely from the perspective of Christ's death and resurrection as well as the sovereignty of God in this regard.

This confession rejects the views of Arminius. To do justice to the views of Arminius, it must be acknowledged that he wanted to fully accept human responsibility without rejecting God's way of salvation. He therefore wanted to explain that God, in his glory, does accept human reasoning (Den Boer 2011:42). However, it must be stated that God's grace is totally undeserved. God's preservation of the believers is totally undeserved. It cannot be rejected or lost. It is not the faith of the believer or the foreseen faith that saves and preserves, but God's total grace.

\section{Davis (1991) explains that according to:}

\begin{abstract}
... conditional understanding of predestination, God's decree is based on the divine foreknowledge of the contingent acts of the human will. God's grace is necessary for salvation but is not alone sufficient, apart from the cooperation of the human will ... This implication of the conditional understanding of predestination, implicit in Arminius, was made explicit in the later Arminian tradition. (p. 222)
\end{abstract}

Davis (1991) also explains that according to the Synod:

\begin{abstract}
The final perseverance of the saints is grounded in God's 'unchangeable purpose of election'. On this point the synod shares common ground with Augustine and Aquinas. The synod goes on to say, however, that final perseverance is also grounded in the nature of regeneration. Even when believers commit serious sin, God 'preserves in them the incorruptible seed of regeneration' and prevents it from perishing or being totally lost. (p. 222)
\end{abstract}

\section{The emphasis on free grace}

Two very important exponents emphasising the free grace of God are Jonker (1989) and Berkouwer (1949).

Jonker (1989:30) explains that the perseverance of the saints is linked to the certainty of faith. Believers can be sure of eternal salvation in faith and of the future with God, because God promises it in Christ. Perseverance of faith is then possible in Christ. For Jonker (1989:126ff.), the Christological emphasis in the election is of the utmost importance. God's sovereignty and freedom of grace must always be linked to his grace as the Father of Jesus Christ and that he can only be known in Jesus. Election must always be understood from the view that God is good, love and light, and that there is no darkness in him. There must never be any doubt that the God who elects is also the God who is good (Jonker 1989:128). His love is, however, holy love and the rejection of this love is revealed as God's anger. The election is in Christ. The wonder of the election should be understood from an infralapsarian perspective. The election is fulfilled in Christ and therefore the believer can be certain of faith and the assurance of the perseverance of faith. The election in Christ can never be annulled (Jonker 1989:129). The love of the Father and Son is the foundation of the election and the perseverance of faith.

Berkouwer (1949) gives much attention to the relation of faith and perseverance. In the midst of the uncertainty of life and the reality of human unreliability, it is difficult to hold to the confession of the perseverance of the faithful. However, Berkouwer (1949:7) explains that the perseverance of the saints is clearly linked to the certainty of faith. In this regard, he refers to Sunday 21 of the Heidelberg Catechism (HC), question 54. An existential tension is clear when there is a reference to Paul who also explains in 1 Corinthians 10:12 that those who think they stand, may fall. There are many references to Israel who did fall into sin (Berkouwer 1949:7). Is the confession of the perseverance of the saints not a flee from the reality of listening and conversion? What must be said it that it is a confession that God is faithful in the border situation of the fragility of human life (Berkouwer 1949:10). Berkouwer (1949:14ff.) explains that the confession of the perseverance of faith is linked to the comfort of the believer. The grace and faithfulness of God is the ground for the confession and not speculative acceptance of continuity. HC Sunday 1 already proclaims this. It is not the aspect of human existence or human reliability, but the faithfulness of God in Jesus Christ that is the foundation of the confession (Berkouwer 1949:18). Dort uses no conceited language on the perseverance and warns that prayer and watchfulness are still needed (Berkouwer 1949:22). It is no false certainty (Berkouwer 1949:23). Falling into sin remains very serious, but God's grace is much greater. Dort is always concerned with the total redemption of the sinner (Berkouwer 1949:25). Extremely important is the comfort for the sinner in the confession of the perseverance of the saints in the Canons of Dort (Berkouwer 1949:26). In the controversies with the Remonstranten, the Roman Catholics and the Lutherans, the Reformed confession proclaimed that the grace of God cannot be lost on our own account (Berkouwer 1949:32ff.). This does not mean that the believer is not warned against sin and the rejection of God, but the confession is found in the love and grace of God (Berkouwer 1949:95) - totally in the grace of God. Even in the test of faith, God remains faithful (Berkouwer 1949:175). Faith, love and perseverance is a unit and therefore the comfort of the confession is so large (Berkouwer 1949:178). This is the only foundation of comfort in times of ordeal (Berkouwer 1949:179). Even when God judges in the final consummation of everything, the believer has the seal of God and will be liberated, because God is capable to do the impossible (Berkouwer 1949:191).

\section{Interpretation of two seemingly opposing periscopes Hebrews 6:4-6}

What about pericopes in the Bible where it seems that faith can be lost and lead to rejection by God? It is necessary to refer to these two pericopes, because they have implications for the understanding of the perseverance of the believers. 
The question raised by Hebrews 6:4-6 is of importance. Knapp (2003) refers to Owen and states:

Consequently, Owen demonstrates through the careful application of 17th century exegetical techniques that the warnings in Heb. 6:4-6 are directed against those who are mere professors of the faith and who, therefore, are not yet fully united with Christ. He rejects the identification of those described in these verses with genuine believers who, through apostasy, lose their salvation. Instead, the text is intended by the author to demonstrate the extent one may go in the Christian religion while yet not possessing salvific faith. (p. 52)

Buchanan (1972:171) explains that there is not a chance of a second repentance, because Christ's sacrifice has a one-forall nature. In Israelite law there was the distinction between sin committed 'unwittingly' and 'wittingly'. The sacrifice of Christ was complete, but those who wittingly reject Christ do not have a new chance. In this sense, the rejection of Christ is complete.

Attridge (1989) emphasises the danger of apostasy and explains that the verses refer to the rejection of the baptismal inclusion of the faith community. In this regard, certain Jewish opinions, which also excludes the possibility of repentance of certain terrible offenses, are 'Apostates, by their rejection of Christ, in effect assume for themselves the shameful repudiation of Christ that the cross implied' (Attridge 1989:171).

According to Bruce (1990:149), the sin committed for which there can be no return, is deliberate apostacy in which the apostate crucifies the Son of God again. In this regard, Peterson (1991) sees apostacy as a possibility:

These passages also teach that apostasy, deliberate defection from the true religion, is a real possibility for members of the covenant community (Heb 12:15-16; 3:12; John 15:2, 6). Church members must be warned of this danger and must exhort one another to persevere in faith and holiness (Heb 3:13). (p. 102)

On the other hand, though, it is also clear that not all who outwardly confess Christ, really do so because of the faith in the Lord Jesus Christ, because they have nothing else to offer him. Some come to Jesus like the seed in the parable of the sower, which grows for a time and then succumbs to all kinds of dangers and persecution and leaves the faith. Therefore, it is important to say that the perseverance of the saints does not mean that God will only distinguish between true and false believers in the end time. Today, God will also distinguish between those who really truly follow him, and those who do not. It is essential to proclaim that God is the One that will keep the believer safe. Therefore, the fear of apostasy is annulled.

\section{John 6:35-37}

Especially from John 6:35-37 it is clear that Christ will keep his promises. It is God's purposes that will prevail (Milne 1993:112).
Burge (2000) writes in this regard:

Therefore, the idea is not about Jesus' welcoming people, but about Jesus' keeping people whom the Father has given into his care. John $6: 37 \mathrm{~b}$ is about the protecting, nurturing capacity of Jesus. This interpretation is confirmed by 6:38: Jesus will not lose a single one of those who have come to him (cf. 10:1-18). (p. 200)

Bruner (2012) also concurs:

Moreover, Jesus apparently believes that his Father will give his Spirit in such measure to those who do come to Jesus that their hearts will overflow with an assurance of their acceptance, of their homecoming, and of their peace with the reconciling Father (recall again the Witness Sermonette in 5:31-40). (p. 409)

Beasley-Murray (1987:92) emphasises that the reason for Jesus' descent (incarnation) to the world is exactly that he will lose no one given to him by the Father. Morris (1971:368) explains that the perfect unity of Father and Son gives the full assurance that those given to the Son by the Father will never be lost.

Hebrews and John do not contradict each other. It explains different positions in the Christian faith. In Hebrews radical apostasy of people rejecting Christ after non-authentic discipleship will not be accepted again. In John, it is all about the Father's eternal promise of authentic belief.

\section{Summative perspective}

Ridderbos (1975) provides the following perspective:

Of course, the certainty and comfort that lie in God's faithfulness and in election in Christ are not again placed in doubt or made contingent on human faithfulness and perseverance, but this certainty is placed and kept within the context where it alone applies and with which the church alone has to do, namely, that of the revelation of the gospel as a power of God for everyone who believes (Rom. 1:16) and thus of the electing character of God's grace, not resting on human power or wisdom, that he who boasts should boast in the Lord (1 Cor 1:16ff.). (p. 353)

Bruce (1977:329) also emphasises that the risen Christ and participation in his risen life will ensure that the believers will have nothing to fear in the final consummation and the final judgement. Goppelt (1982:141) also emphasises that justification, as Paul understood it, means that one is served justification to put man in a final place of relationship before God. Kärkkäinen (2013:357) regards the resurrection as an event that is eschatological, but in the sense that it points to the future of this world, and creation is a profound evidence of the God's faithfulness. However, this is, in his view, not limited to the believers, but John clearly links it to the believers.

\section{It is a comfort in many times of persecution}

In an explanation of the suffering of Christians in the Bad Urach Statement, made by 24 participants of at least 18 different countries from 16 to 18 September 2009 on an 
evangelical theology of suffering, reference is made to the reality of the suffering of Christians (Sauer 2012:14). Suffering is described by Jesus as part and parcel of discipleship. There are many different aspects to suffering and the reaction towards suffering also differs, but Christians have to engage in mission as they engage in the confession of Christ during suffering. Suffering is, however, always challenging and extremely difficult to endure. It is therefore essential to have the assurance that Christ will keep the believers safe in suffering and that they will persevere in faith.

Schirrmacher (2008:16ff.) explains how persecution of Christians and martyrdom in the present world is still prevalent after the fall of communism. Presently the crises in the Middle East and elsewhere regarding struggles in Islam lead to an exponential rise in martyrdom (167000 in 2001 and still rising). It is clear that wide sections of the church are persecuted. Schirrmacher (2008:50) explains that martyrdom is 'part of the church, part of its very essence and suffering is the mark of mission'. Many atrocities still happen such as the recent attack on churches in Sri Lanka and the Boko Haram attacks on churches in Nigeria.

Schnabel (2004:1553) did impressive research on early Christian mission. He explains how the Christians unashamedly proclaimed that the Gospel of the crucified and risen Christ is from God and they refused to contextualise the Gospel in such a way that the provocative, alien or scandalous elements disappear. In many instances, they had to suffer martyrdom. The courage of the martyrs, however, impressed the crowds to such an extent that a powerful God was acknowledged.

It is also very important to look at some of the earliest times of persecution, especially during the time of the Roman Emperors. Fernandez (2013:157) explains how the persecution under Emperor Diocletian, when more than half of the martyrs of the Christian world were killed by, among others, wild animals, remains the reference of all persecution. Visalli (1992:170-171) explains how severe the persecution was, because Christians did not want to sacrifice according to the command of the Emperors. They were mocked, hit with sticks, burnt alive and beheaded. Some persevered until the end; others obeyed the commands and returned to pagan temples. After the persecution, penance for the Christians was a serious issue. Different views existed and some accepted that Christians could be readmitted by confession only. Cyprian had a stricter view and under his leadership, the Synod of Carthage decided that certain rules applied. Hardliners, however, had the view that no one who lapsed should be reinstated in the church. Many were clamouring for readmission. The perseverance of faith was therefore not because of their own doing, but because of God's grace. For over 2000 years, it has not subsided. Coptic Christians suffer much and Boko Haram in Nigeria kills many. Fernandez (2013:157) is of the opinion that religious persecution remains massive and that, although many churches and organisations offer much help, a comprehensive effort by the international community is needed. It should be made an urgent issue of international criminal justice (Fernandez 2013:170).

Furthermore, in the mission history it is very important to notice that many Christians suffered much from those who did not accept them. Especially in countries such as China, India and the Middle East, it was difficult for Christians to keep the faith under challenging circumstances. One must acknowledge that it was always difficult to proclaim that, to be in Christ, you are safe when people around you are attacking you, churches are burnt and many other things happen to Christians. The important thing is, however, that many Christians can attest to the fact that, during these times of persecution, God revealed himself often in a wonderful way to them and in his benevolence to them.

The important question from Welker (2013:235-236) is whether the persecutions and tribulations of this world, which are even more present for Christians than the normal hardships of life, should be endured, because they expect compensation in heaven. Welker (2013:235-236) is of the opinion that Christ's life on earth does not strengthen such a view and that he was interested in the life of the here and now, and that much joy may even now be experienced. Persecution should, however, be endured with the eye on God's new creation.

In the endeavour of mission, the confession of the perseverance of the saints can be a very important message of great comfort to be proclaimed to all. Many people may be worried that if they have become a Christian and experience persecution they will then lose their faith, be rejected by God and suffer damnation. Yet, the canon of the perseverance of faith emphasises that God, in his great benevolence, will never reject them. This can be proclaimed in mission. Mission is not only about bringing a person to Christ, but also is about nurturing a person, helping a person and empowering a person. It is important that the perseverance of the faith must be proclaimed to the believers and must also be an invitation to others to faith.

It is also important to notice that many missionaries proclaim that they experience this in their spiritual life while they proclaim the Word of God in very difficult circumstances when they go out into the world and are challenged in many ways, but keep steadfast so that many may hear this message of God's grace.

Grell (2011) also explains how Calvinism spread throughout the world by believers keeping the faith in the sovereignty of God amidst persecution:

This international Calvinist network, including the theology which underpinned it, could not, in my opinion, have emerged without the prolonged experience of persecution and subsequent exile which came to characterise early modern Calvinism. Holding unto their confession they influenced the world. (p. 2)

In Jesus Christ, there is certainty of eternal life. This certainty of eternal life does not come from humans. Certainty in this 
life may be challenged often. Many things that people are certain of, are rejected in time, but certainty in faith in Jesus Christ is because the certainty comes through the Holy Spirit proclaiming that Jesus is the One that saves. The certainty of eternal life lies in Jesus Christ himself. It lies in the message that he has given this assurance through the cross where he yielded himself up for many

Therefore, theological and philosophical views that emphasise uncertainty and a worldview of uncertainty must be challenged. In the postmodern and even post-postmodern world, there is much uncertainty. Philosophical ideas continue in this vain. Challenging these concepts and the perseverance in faith of the believers emphasises that the Christological explanation of election serves to give full assurance in a world full of doubt and uncertainty. Janse van Rensburg (2000:53) clearly explains that it is necessary to regard the essential aspects of postmodernism as unbiblical, as it disallows for the aspect of absolute truth in the Christian religion and 'defies the very essence of unity in truth'.

The confidence in the perseverance of the saints empowers the believer in the most difficult circumstances and he or she can acknowledge that God is the One that will keep them safe for time and eternity. The truth of faith is found in God, not in human possibilities. The challenge to faith on the premise that there is no certainty must be rejected, because God is the One who keeps them safe. His truth is different from the truth of the world, and his promises are eternal. In this regard, this truth guides the church to fullness of service to the triune God. There must be a realisation of the biblical, theocentric, and Christocentric religion (Beeke 2009:330). Therefore, it is possible to proclaim the Word of the triune God to all - even in times of persecution. Mission becomes then a wonderful act of peace for a troubled soul in a troubled world. When it is proclaimed in the world that Jesus is the One to put your faith and trust in, the knowledge of the perseverance of this saint also helps us to understand how we should continue in this world, and how we should continue to live and to proclaim the Word of God. Therefore, mission is not proclaimed with a message of doubt and uncertainty. It must always be proclaimed that the perseverance in the faith of the saints is the way in which we can proclaim peace and wonder for those who believe in Christ.

\section{Conclusion}

The confession of the perseverance in faith in the Canons of Dort is therefore very relevant as a clear and powerful missionary statement. Election of the believers and in the perseverance of the believers is therefore not a rejection of the calling to faith in mission. It must be recognised that mission is enhanced even though it is stated that God's grace is the essence of the proclamation.

\section{Acknowledgement Competing interest}

The author declares that no competing interest exists.

\section{Author contributions}

I declare that I am the sole author of this research article.

\section{Funding}

This research received no specific grant from any funding agency in the public, commercial, or not-for-profit sectors.

\section{Data availability statement}

Data sharing is not applicable to this article as no new data were created or analysed in this study.

\section{Disclaimer}

The views and opinions expressed in this article are those of the authors and do not necessarily reflect the official policy or position of any affiliated agency of the authors.

\section{Ethical consideration}

This article followed all ethical standards for carrying out research without direct contact with human or animal subjects.

\section{References}

Attridge, H.W., 1989, Hebrews, Fortress, Philadelphia, PA. (Hermeneia). Beasley-Murray, G.R., 1987, John: Word books, Waco, TX. (Word Biblical Commentary, 36). Beeke, J.R., 2009, Reformatorische spiritualiteit, De Groot Goudriaan, Kampen. Berkhof, H. \& De Jong, O.J., 1975, Geschiedenis der kerk, Callenbach, Nijkerk. Berkhof, L., 1978, The history of Christian doctrines, Banner of Truth, Edinburgh. Berkouwer, G.C., 1949, Dogmatische Studiën: Geloof en volharding, Kok, Kampen. Bruce, F.F., 1977, Paul, apostle of the free spirit, Paternoster, Exeter.

Bruce, F.F., 1990, The epistle to the Hebrews, rev. edn., Eerdmans, Grand Rapids, MI. (NICNT).

Bruner, F.D., 2012, The gospel of John: A commentary, Eerdmans, Grand Rapids, MI.

Buchanan, G.W., 1972, To the Hebrews: A new translation with introduction and commentary, Doubleday, New York. (The Anchor Bible).

Burge, G.M., 2000, John, Zondervan, Grand Rapids, MI. (The NIV Application Commentary).

Calvin, J., 1960, Institutes of the Christian religion, transl. F.L. Battles, Westminster Press, Philadelphia, PA.

Davis, J.J., 1991, 'The perseverance of the saints: A history of the doctrine', Journal of the Evangelical Theological Society 34(2), 213-228, viewed 29 November 2018, from https://search.ebscohost.com.ezproxy.ufs.ac.za/login.aspx?direct=true\&db=rfh\&A N=ATLA0000839521\&site=ehost-live.

Den Boer, W., 2011, Defense or deviation? A re-examination of Arminius's motives to deviate from the 'Mainstream' reformed theology, in A. Goudriaan \& F. van Lieburg, Revisiting the Synod of Dort (1618-1619), pp. 23-48, Brill, Leiden. (Brill's series in church history, 49).

Fernandez, L., 2013, 'Religious persecution as a crime against humanity', Internationa Journal of Religious Freedom 6(1 \& 2), 157-172.

Goppelt, I., 1982, Theology of the New Testament: The variety and unity of the apostolic witness to Christ, vol. 2, transl. J.E. Alsup, Eerdmans, Grand Rapids, MI.

Grell, O.P., 2011, Brethren in Christ: A Calvinist network in reformation Europe, Cambridge University Press, Cambridge.

Inst. see Calvin 1960

Janse van Rensburg, J., 2000, The paradigm shift: An introduction to postmodern thought and its implications for theology, Van Schaik, Pretoria.

Jonker, W.D., 1989, Uit vrye guns alleen: Oor uitverkiesing en verbond, NGKB, Pretoria. (Wegwysers in die dogmatiek).

Kärkkäinen, V-M., 2013, Christ and reconciliation: A constructive Christian theology for the pluralistic world, vol. 1, Eerdmans. Grand Rapids, MI.

Knapp, H.M., 2003, 'John Owen's interpretation of Hebrews 6:4-6: Eternal perseverance of the saints in Puritan exegesis', The Sixteenth Century Journal $34(1), 29-52$, viewed 29 November 2018, from https://search.ebscohost.com.

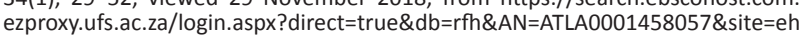
ost-live. 
MacArthur, J., 1993, 'Perseverance of the saints', The Master's Seminary Journal 4(1), 5-24, viewed 29 November 2018, from https://search.ebscohost.com. ezproxy.ufs.ac.za/login.aspx?direct $=$ true $\& d b=r f h \& A N=A T L A 0000864$ $502 \&$ site $=$ ehost-live

McGrath, A., 1994, Christian theology: An introduction, Blackwell, Oxford.

Migliore, D.L., 2004. Faith seeking understanding: An introduction to Christian theology, Eerdmans, Grand Rapids, Ml.

Milne, B., 1993, The message of John, InterVarsity, Downers Grove, IL.

Morris, L., 1971, The Gospel according to John, Eerdmans, Grand Rapids, MI. (NICNT).

Peterson, R.A., 1991, 'The perseverance of the saints: A theological exegesis of four key New Testament passages', Presbyterion 17(2), 95-112, viewed 29 November 2018, from https://search.ebscohost.com.ezproxy.ufs.ac.za/login.aspx?direct=tru $\mathrm{e} \& \mathrm{db}=\mathrm{rfh} \& A N=A T L A 000848483 \&$ site=ehost-live.

Reformed Church in America, 2018, Canons of Dort, viewed 29 November 2018, from https://www.rca.org/resources/canons-dort.

Ridderbos, H., 1975, Paul: An outline of his theology, transl. J.R. de Witt, Eerdmans, Grand Rapids, MI.

Sauer, C. (ed.), 2012, Bad Urach statement: Towards an evangelical theology of suffering, persecution and martyrdom for the global church in mission, Culture and Science Publishing, Bonn.(The WEA Global Issues series, 9).
Schirrmacher, T., 2008, The persecution of Christians concerns us all, Culture and Science Publishing, Bonn. (The WEA Global Issues series, 9).

Schnabel, E.J., 2004, Early Christian mission: Paul and the early church, vol. 2, InterVarsity, Downers Grove, IL.

Sinnema, D., 2011, 'Calvin and the Canons of Dort (1619)', Church History and Religious Culture 91(1-2), 87-103, viewed 29 November 2018, from https:// search.ebscohost.com.ezproxy.ufs.ac.za/login.aspx?direct=true\&db=rfh\&AN=ATL A0001849069\&site=ehost-live.

Van der Walt, B.J., 2011, 'Die gereformeerd-skolastieke visie op die verhouding tussen God en mens by F. Gomarus (1563-1641) en J. Arminius (1560-1609): ' $n$ Historiesfilosofiese ondersoek', Tydskrif vir Geesteswetenskappe 51(3), 269-288.

Van der Walt, B.J., 2012, 'Aristotelies-filosofiese invloede by die Sinode van Dort (1618-1619) en die bevrydende perspektief van 'n reformatoriese filosofie op goddelike soewereiniteit en menslike verantwoordelikheid, Tydskrif vir Geesteswetenskappe 52(2), 174-195.

Van der Westhuizen, H., 2018, 'The trinity in the Canons of Dort?' In die Skriflig 52(2), a2338. https://doi.org/10.4102/ids.v52i2.2338

Visalli, G., 1992, After Jesus: The triumph of Christianity, The Readers Digest Ass. Inc., New York.

Welker, M., 2013, God the revealed: Christology, expanded version of the Gunning lectures in Edinburgh, 2004, transl. D.W. Stott, Eerdmans, Grand Rapids, MI. 